\title{
THE UNITED NATIONS HUMAN RIGHTS COMMISSION AND THE SEARCH FOR MEASURES OF IMPLEMENTATION
}

\author{
R Q Quentin-Baxter
}

The major assets of the Human Rights programme are substantial, and some of them are easily counted. The Universal Declaration - championed by Cassin and chronicled by Sohn ${ }^{1}$ - has enlarged the meaning of the human rights provisions of the United Nations Charter, and is within the frame of reference of almost every United Nations debate. Lauterpacht ${ }^{2}$ laid the foundations for sound legal development by tracing the Charter provisions to their heritage in existing law. Other writers ${ }^{3}$ of the first rank have helped to change the perspectives of international law to conform with the Charter goals of universality and of ultimate concern for individual human rights. It is the measure of these changes that the Secretary-General of the International Commission of Jurists, writing in celebration of Human Rights Year, is able to affirm:

The Universal Declaration does now represent in written form the basis for the law of nations, the laws of humanity and the dictates of the public conscience as accepted in the 20th Century.

Unfortunately, this message has not yet made much stir outside the small world of scholarship. The cause of human rights can hardly be more effective than the world organisation it serves; and neither commands the ultimate loyalty of sovereign states. For the peoples of these sovereign states, the transactions of the United Nations are often little

- Professor of Law, 1968-1984.

1 Joumal of the International Commission of Jurists, Special issue for Human Rights Year.

2 Hersch Lauterpacht, International Law and Human Rights (Stevens, London, 1950).

3 Wolfgang Friedman, The Changing Structure of International Law (Columbia University Press, New York, 1964); Wilfred Jenks, The Common Law of Mankind (Praeger, New York, 1958). 
more than a shadow-play, bearing repeated and unwelcome witness to the jealousies, inequalities and irrationalities of a bitterly divided world.

There are areas within which such negative forces may yield to a constructive sentiment. The sheer necessities of modem living demand the international regulation of postal and telecommunication services, aviation, quarantine and a host of other practical matters: in these respects sovereign states will accept direction as submissively as any ratepayer. The claims of humanity are a less insistent voice, but not a negligible one: under the spur of an enlightened public opinion, Governments contribute more or less generously to international aid projects - though without the sense of commitment which they feel for the relief of want in their own national communities.

In other areas there is no comparable public demand for action which transcends narrowly conceived national interests. Between the conception of a world order and its actuality falls the shadow of state sovereignty. National and supra-national goals are reconciled only in limited contexts or exceptional cases. In the field of labour relations where there has been some tradition of solidarity across national frontiers in the confrontation between workers and employers - international regulation has achieved its greatest success. Among Western European countries which already feel a compulsion to pool their resources and destinies, regional institutions in the human rights field have quietly attained a position of real authority.

The United Nations, lacking the propellant of Great Power unanimity or of dedicated world-wide popular support, has in a sense always been dependent on auxiliary sources of energy. By far the most constant of these auxiliary sources have been the rising demands of the newly independent and less developed countries for an end to colonialism and to racial discrimination, and for better standards of living. It was natural that these demands should find expression not only in the committees concerned with concrete political problems. From the early days of the United Nations, the process of formulating standards has been carried on in the Third Committee of the General Assembly and it has been the responsibility of the Human Rights Commission to furnish drafts.

At first it must have seemed almost a non-political task to give general currency to the constitutional guarantees which older democratic countries have usually accorded their own citizens. Before long, however, the representatives of those countries were cast in the role of defenders of privilege. The ideological battles were hard fought and long drawn out. The disputed right of self-determination, at length made its way into both draft United Nations Covenants. Economic and social rights were sometimes accorded a priority over civil and political rights and freedoms. The draft Covenants were themselves delayed so that priority might be given to the completion of the Convention on the Elimination of Racial Discrimination. 
The major decisions taken by the General Assembly in human rights matters are therefore part and parcel of the international political process. They have, for example, helped to mould a climate of United Nations opinion which calls for the earliest possible end to colonial regimes, and which reserves its deepest opprobrium for the practice of apartheid. Yet the discussion of human rights questions in United Nations bodies is, for the most part, a debate without an audience. Government representatives may reflect accurately enough the outlook of the public in their own countries, but their action creates little awareness or sense of involvement among their countrymen.

Human Rights Year was then a time for stock taking. In the international sphere, the concept of human rights had proved to be a powerful political catalyst. In the domestic sphere, the standards proclaimed in the Universal Declaration were widely recognised. There, were, however, still no international procedures to vindicate the rule of law; and there was no assurance that states would voluntarily assume the obligations set out in the Covenants so recently adopted by the General Assembly.

It was frequently said that the era of international legislation must be followed by a period of concentration upon measures of implementation; and the Human Rights Commission has already turned its attention to that task. The remainder of this paper will trace the Commission's efforts, and will attempt an assessment of their prospects of fruition.

\section{THE ACTION TAKEN BY THE HUMAN RIGHTS COMMISSION}

At its 1966 session, the Commission received from the Economic and Social Council (in resolution $1102(\mathrm{XL})$ ) an invitation:

to consider as a matter of importance and urgency the question of the violation of human rights and fundamental freedoms, including policies of racial discrimination and segregation and of apartheid in all countries, with particular reference to colonial and other dependent countries and territories, and to submit to the Council at its forty-first session its recommendations on measures to halt those violations.

The Council's request was specifically related to complaints about conditions in Southern Africa, and the general wording of the passage quoted was regarded in some quarters as no more than a token concession to the principle of impartiality.

In the Commission, the Soviet representative in fact proposed that action should be confined to the cases of dependent territories; but this view was not upheld by the majority. The resolution finally adopted $(2(X X I I))$ included a separate Part which addressed the Council in these terms:

Informs the Council that, in order completely to deal with the question of violations of human rights and fundamental freedoms in all countries, it will be necessary for the Commission to 
consider fully the means by which it may be more fully informed of violations of human rights with a view to devising recommendations for measures to halt them.

The Commission decided also to consider at its next session:

the question of the Commission's tasks and functions and its role in relation to violations of human rights in all countries... ,

with special reference to situations in Southern Africa. This first step to review the Commission's procedures, taken with the support of not less than fifteen of the Commission's twenty-one members, was in due course approved by both the Council and the General Assembly.

In 1967 the Human Rights Commission, now enlarged to thirty-two members to provide a better balance of representation from Africa and Asia, decided (in resolution 8(XXIII)) to give annual consideration to the question of violations and asked the Sub-Commission on the Prevention of Discrimination and Protection of Minorities to prepare a report on violations from all available sources. This important resolution went on to seek a revision of the decisions under which the Commission had, from its inception, denied its own authority to take action in regard to complaints:

4. Requests the Economic and Social Council to authorise the Commission and the SubCommission ... to examine information relevant to gross violations of human rights and fundamental freedoms, such as apartheid in all its forms and manifestations...

5. Further requests authority, in appropriate cases, and after careful consideration of the information thus made available to it ... to make a thorough study and investigation of situations which reveal a consisent pattern of violations of human rights, and to report with recommendations thereon to the Economic and Social Council;

6. Invites the Sub-Commission to bring to the attention of the Commission any situation which it has reasonable cause to believe reveals a consistent pattern of violations of human rights and fundamental freedoms, in any country, including policies of racial discrimination, segregation and apartheid, with particular reference to colonial and other dependent territories.

The resolution was sponsored by the delegations of Costa Rica, Dahomey, the Philippines, Senegal and Sweden; and its crucial fifth paragraph was adopted with twentyfive votes in favour, three against, and three abstentions. The representatives of Soviet bloc countries argued that it was beyond the Commission's authority and capacity to undertake action of a political, judicial or semi-judicial nature; but the argument received little other support. 
The Economic and Social Council acceded (in resolution 1235(XLII)) to the Commission's requests, while the Sub-Commission surprised its parent body by drawing attention (in resolution $3(X X)$ ) to situations which revealed "consistent patterns of violations of human rights" in Greece and in Haiti. Thus, at its 1968 session, the Commission was for the first time confronted with a proposal for action in regard to an alleged violation of human rights occurring elsewhere than in southern Africa. There was great uncertainty and difference of opinion about the response the Commission should make. In the extreme view of the Tanzanian representative, the Sub-Commission should be rebuked for turning its attention to situations other than those arising in southern Africa. In the view of many other delegates, the Sub-Commission had acted properly, but the available information would not warrant any conclusion condemning the Governments of Greece or Haiti. Some felt that, in the absence of a preliminary examination, it would be difficult to exclude political considerations from the Commission's debate. Some attacks were made upon Greece, and upon other states in the course of debate. Some representatives, though feeling that nothing should be done on this occasion, reaffirmed their support for the procedure to study consistent patterns of violations. By tacit agreement it was at length decided that no proposal would be pressed to the vote.

At its 1969 session the Commission received from the Sub-Commission (in resolution $2(X X I))$ a proposed procedure for dealing with situations which appeared to reveal a consistent pattern of gross violations of human rights and fundamental freedoms. The SubCommission's proposal, after the incorporation of minor amendments designed to strengthen the safeguards, was adopted as resolution $17(X X V)$. This resolution authorises the SubCommission

to appoint a working group consisting of not more than five of its members, with due regard to geographical representation, to meet once a year in private meetings ... immediately before the sessions of the Sub-Commission to consider all communications ... with a view to bringing to the attention of the Sub-Commission those communications, if any, which reveal a consistent pattern of gross violations of human rights and fundamental freedoms within the terms of reference of the Sub-Commission.

The Sub-Commission is asked to consider in private meetings the communications brought before it in accordance with the decision of the majority of the working group. If the Sub-Commission then refers the matter to the Commission for further action, the Commission will decide whether to embark on a full-scale investigation or, with the consent of the state concerned, to appoint an ad hoc committee to look into the matter. All of the steps taken by the Sub-Commission and by the Commission will remain confidential unless and until the Commission decides to report to the Economic and Social Council.

In short, the procedure favoured by the Commission places its faith in quiet negotiation, and contemplates publicity only as a last resort. The requirement for preliminary screening 
also protects the interest of the state under suspicion, for the representatives of three of the main regional groups are required to produce a majority in the working group. This resolution as a whole was adopted by fourteen votes in favour, four against, and ten abstentions; but its key paragraph survived a motion to delete only on an equality of votes. The matter will be taken no further during the present year, as the Economic and Social Council has decided to seek the views of governments before acting on the Commission's recommendation.

There are two other matters which call for briefer mention. In 1967 the delegations of Costa Rica, Dahomey, the Philippines, Senegal and Sweden sponsored a draft resolution (14(XXIII)) recommending the General Assembly to establish the office of United Nations High Commissioner for Human Rights, and outlining the High Commissioner's status and duties. He would "possess the degree of independence and prestige required for the performance of his functions under the authority of the General Assembly". He could upon request give advice to any organ of the United Nations concerned with human rights; could render assistance to any member state; would have access to all communications concerning human rights; and would report on the progress made in giving effect to human rights instruments.

These provisions followed the recommendations of the Working Group set up by the Commission a year earlier, and it was stressed that the High Commissioner would in no way impose his or her will on governments. Even so, the proposal was vigorously opposed by a minority consisting of the three Soviet bloc delegations, together with those of India, Iraq, the United Arab Republic, and Yugoslavia. These seven countries voted against the resolution; France and Nigeria abstained; but the resolution had the support of twenty delegations.

The General Assembly has not acted on the proposal to appoint a High Commissioner for Human Rights, and opinion within the United Nations is probably more evenly divided on this issue than the Commission's vote would indicate. Even the staunchest supporters of the High Commissioner proposal have tended to recognise that the value of the office would depend on the goodwill which is commanded. With no consensus in view, it is perhaps unlikely that the issue will be revived in the early future.

Finally, there was a proposal, pressed by Nigeria in 1967 and 1968, noting the existence of regional commissions on human rights in Western Europe and in Latin America, and establishing a Study Group to consider the question of creating similar bodies in other regions. The proposal received no very determined support, and was emphatically opposed by India and by the Soviet bloc countries. Predictably, the Study Group set up in 1967 could reach no consensus; and the Commission, faced with this result, merely referred the matter to Governments. 
The point which most clearly emerges is that India, with some justification, regards her vast population as a region in itself, and is unwilling to be grouped with smaller and unsympathetic neighbours. For the rest, the Nigerian initiative probably gives little indication of the prospects of regional development. Wherever there is opportunity for consolidation of national attitudes and defence of common standards, regional or subregional groupings will have an appeal. It is particularly noteworthy that the question of African regional development will this year be discussed at a human rights seminar to be held in Cairo.

\section{SOME CONCLUSIONS}

It is worth stressing that, on human rights issues, there is seldom a rigid voting pattern. A project such as that of establishing the office of High Commissioner has many enemies; but it also has warm, active support in every regional grouping except that of Eastern Europe. The critical vote on setting up a procedure to deal with complaints about violations of human rights was more polarised: but the Philippines and Iran adhered to the predominantly Latin American and Western European position supporting the procedures recommended; Italy voted with those opposed, in the company of the Eastern Europeans, and of most Asians and Africans; Austria, France, Greece, Pakistan and the Congo abstained.

On any question of including references to colonialism or racial discrimination the Western dissenters will of course be isolated, but they will usually obtain substantial and varied support in resisting a move to confine the thrust of a general recommendation to colonial matters.

This small margin of latitude for even-handedness - not very common in political decision-making - is one of the main reasons for choosing to raise issues in a human rights context. Doctrine was forged in the Third Committee in regard to such questions as "selfdetermination" because states - which might have been inhibited in casting a vote against the particular interest of a friendly power - felt free to declare their true colours in a "nonpolitical" vote of general principle.

Conversely, the need to declare a general position, instead of voting inscrutably on a particular issue, might pose a problem of consistency for a delegation which was vulnerable to reason. This was, and is, an object of manoeuvre - and, more than that, a way of enlarging the no-man's land in which actions have their real value.

In the field of human rights, one hopes to get a step nearer the truth. That is why some delegations find it worthwhile to uphold a single standard - knowing that a vote won under these conditions has an enhanced value. For similar reasons, and believing in their cause, delegations may welcome the institution of a complaints procedure. A verdict against apartheid in a semi-judicial proceeding is worth more than the registration of an automatic majority vote. 
It does not follow that delegations will feel able to support a policy of objectivity, if their own national record seems impeachable. "To the sovereign nation-state, its own needs and conscience are the ultimate criteria of right and wrong and of law and justice". ${ }^{4}$ It is no reproach to the doctrine of human rights that it shares the peril which unbridled national sovereignty poses for international order.

De Visscher, sharing Lauterpacht's esteem for "the profound influence of human values in the establishment of an international order", gives his customary warning about building legal castles in the air. "The bond that is being established beyond any shadow of doubt between the rights of man on the one hand, and the maintenance of peace and respect for law on the other, constitutes the first assertion of the international organisation of a great moral and civilising principle. We must neither count upon its immediate efficacy, nor reject the hopes that it awakens". 5

For Moskowitz, there can be no rest or respite until the dragon of national sovereignty has been slain. Tirelessly he exposes the monster's capacity for evil and its immunity to half-measures. To escape the curse, mankind must undergo nothing less than a spiritual and intellectual conversion. The aims of the Charter must be fulfilled. "The true and concrete incarnation of the international idea is man himself ${ }^{\prime}{ }^{6}$

My head is with de Visscher and my heart is with Moskowitz. It seems to me clear enough that there can be no co-existence with the dragon of national sovereignty. If we cannot close ranks against him, he will make fools of us all. In that not unlikely event, there will still be value in cleaving to the doctrine of human rights at whatever level of achievement has proved attainable. Even if the goal of international protection were abandoned, the doctrine would still have a capacity to humanise, and to reconcile ideological differences. That has been put persuasively by Bystricky of Czechoslovakia: ${ }^{7}$

I should like to point out that the problem of human rights and freedoms is once again a topic of penetrating debate in the socialist countries....The tendency is to abandon the deep-rooted idea that there is a higher interest of society in contrast to the subordinate interests of the individual and that the purpose of law is to bridge these contradictory interests of the individual and society....In my country - and, I suppose, in other socialist countries as well -

4 Moses Moskowitz The Politics and Dynamics of Human Rights (Oceana Publications, New York, 1968) [The Politics and Dynamics of Human Rights].

5 Charles de Visscher Theory and Reality in Public International Law (Princeton University Press, Princeton, 1968) 126, 134.

6 The Politics and Dynamics of Human Rights above n 4, 210.

7 Bystricky in Eide \& Schow (eds) Nobel Symposium 7 International Protection of Human Rights (1968) 91-2. 
political theory has discarded its previous and erroneous views on the total discontinuity of the development of human and civil rights, and is closely following the trends in democratic world public opinion and political practice. 
(1999) 30 VUWLR 